УДК 612.616.2-092.9:537.8:613.168

DOI: $10.24061 / 1727-0847.18 .4 .2019 .8$

\title{
O M.Uарапова
}

ДЗ «Дніпропетровська медична академія Міністерства охорони здоров'я України», Дніпро

\section{ВИДОЗМІНЕННЯ ФОРМ СПЕРМАТОЗОЇДІВ У ЯСЧКАХ ЧОЛОВІКІВ ІЗ ЗАПАЛЬНИМИ ЗАХВОРЮВАННЯМИ СЕЧОСТАТЕВОЇ СИСТЕМИ}

\begin{abstract}
Резюме. У цій роботі висвітлені відомості про процес формування статевих клітин у чоловіків із запальними захворюваннями статевих органів, що піддалися дії електромагнітного поля. Спостереження за сперматозоїдами показало, що живих клітин нараховувалося більше, ніж неживих (50,19 \% та 49,81 \% відповідно). У процесі спостереження з'ясовано порушення рухомості клітин у бік збільшення кількості нерухомих клітин до 37,4 \% і малорухомих - до 56,33 \%. Вплив електромагнітного поля призводив до порушення процесу сперматогенезу на етапі формування пізніх сперматид та сперматозоїдів. У результаті некоригованого розходження акросом статевих клітин формувалися клітини з подвійними головками, деформованими шийками та роздвоєними хвостами. Найбільшої деформації піддалися головки сперматозоїдів, яких нараховано 32,6 \%, змін структур шийки визначено 7,21 \% і змін структур хвостів клітин $-3,72 \%$.
\end{abstract}

Ключові слова: електромагнітне поле, сперматозоїд, акросома, рухливість.

Вирішення проблеми лікування безпліддя в країні набуває великого значення у зв'язку зі збільшенням кількості хворих чоловічої статі на запальні захворювання, що може спричинятися багатьма факторами. Рівень безпліддя в країні досягає 30 $40 \%$, у ньому чоловічий фактор становить більшу частину в структурі захворювань [1]. Призвести до виникнення безпліддя можуть різні фактори, 3 них найбільш вірогідні - це несприятливі екологічні обставини, психологічні аспекти взаємовідносин між подружжям, спадкові фактори, хронічні запальні захворювання [2]. Дія несприятливих екологічних факторів може викликати появу запальних захворювань чоловічих статевих органів [3]. 3 екологічних факторів необхідно виокремити радіоактивний вплив на людей у результаті діяльності атомних електростанцій, хімічних підприємств, випромінювання електромагнітних хвиль від установок на металургійних, гірничовидобувних підприємствах, електропідстанціях, що виробляють електроенергію $[4,5]$. У побуті людина також відчуває на собі вплив електромагнітних хвиль - випромінювання від побутових приладів, найбільш несприятливим 3 яких є вплив електромагнітних хвиль від мікрохвильових печей. Враховуючи вище наведені відомості, визначення впливу шкідливих факторів зовнішнього середовища, зокрема електромагнітного поля на чоловічу статеву функцію і сперматогенез є актуальною проблемою сучасної медицини [6].

Мета дослідження: визначення негативного впливу електромагнітного поля на виникнення запальних захворювань у чоловіків, визначення кількості деформованих форм статевих клітин.

Матеріал і методи. Під наглядом перебували 33 хворі віком від 18 до 44 років із запальними захворюваннями статевих органів, руйнування проиесу сперматогенезу в яких оцінювалося за ступенем появи патологічних форм сперматозоїдів на всіх стадіях сперматогенного ииклу. Оиінювалися спермограми чоловіків, що здавали аналізи в лабоpamopiï «In Vitro» м. Дніпра. При обробичі аналізу враховувалися такі показники: кількість епітеліальних клітин уретри, простати, лейкоцитів в 1 мл сперми, кількість сперматозоїдів у 1 мл, загальна кількість сперматозоїдів, кількість нормальних і патологічних форм клітин у відсотковому співвідноменні.

Проводили підрахунок життєздатних $і$ нежиттездатних клітин. Живі клітини оцінювалися за ступенем рухомості. Підраховувалися клітини: активні, але малорухомі; клітини без поступальних рухів і нерухомі. Паралельно проводився підрахунок неживих сперматозоїдів.

Також проводили спостереження за клітинами з нормальною будовою та появою патологічних форм сперматозоїдів. Із патологічних форм чоловічих статевих клітин у відсотковому співвіднотенні підраховували клітини з патологією головки, шийки та хвоста. При запальних захворюваннях чоловічих статевих органів, викликаних дією електромагнітного поля, відбувається пору-

(C) Шарапова О М., 2019 
шення утворення сперматозоїдів на стадії мітотичних $і$ мейотичних ділень. Акросоми на раніх стадіях розвитку клітин розходяться несинергічно, внаслідок чого утворюються клітини з подвійними головками та роздвоєними джгутиками.

Результати дослідження та їх обговорення. Люди, що знаходилися під наглядом, перебували в шкідливих умовах виробництва: під дією електромагнітних хвиль на металургійних, гірничовидобувних, хімічних підприємствах. Меншою мірою досліджувані особи відчували також на собі дію електромагнітного поля, що випромінювали електричні побутові прилади: холодильники, мікрохвильові та електричні газові печі, телевізори, мобільні телефони.

При мікроскопічному дослідженні сперми встановлено, що в аналізах чоловіків з гострими та хронічними запальними захворюваннями в полі зору спостерігалися поодинокі епітеліальні клітини уретри та простати у стані жирової дистрофії, лецитинові зерна та амілоїдні тільця в незначній кількості, поодинокі сперматофаги. Кристали Бетхера не визначалися в жодному аналізі.

Про виражений запальний процес в яєчках чоловіків, що відчували на собі вплив електромагнітного поля, засвідчили такі фактори, як наявність в аналізах сперми значної кількості лейкоцитів в 1мл рідини. Їх кількість у більшості пацієнтів нараховувалася від 50000 до 200000 клітин.

У результаті дослідження також з'ясовано, що в аналізах хворих середнє значення кількості сперматозоїдів у спермі чоловіків мало значення 56,4 млн. в 1 мл, загальна кількість сперматозоїдів досягала середніх значень в 216,55 млн. в 1 мл.

У спермальних аналізах кількість живих і неживих сперматозоїдів мала приблизно однакові значення, але більше все ж таки нараховувалося живих статевих клітин, ніж неживих (живих $50,19 \%$, неживих $-49,81 \%$ ).

Подальший аналіз сперми показав, що 3 життєздатних статевих клітин активних, але малорухо- мих сперматозоїдів нараховувалося $37,4 \%$, клітин без поступальних рухів - 6,54 \% та нерухомих сперматозоїдів - 56,33 \%. При підрахунку неживих сперматозоїдів ми одержали середнє значення в 49,81\%. (табл. 1). Нерухомі сперматозоїди мали найбільшу відсоткову частку в структурі життєздатних клітин. При запальних захворюваннях чоловічих статевих органів у чоловіків, що зазнали шкідливого впливу електромагнітного поля, найбільшу частку у структурі життєздатних статевих клітин мають малорухомі сперматозоїди, тобто виникає найбільша втрата здатності статевих клітин до поступальних рухів. Ці відомості вірогідніше виступають причиною виникнення безпліддя у чоловіків і визначають роль чоловічого фактора у безплідному шлюбі.

При вивченні структури сперматозоїдів в аналізі сперми чоловіків із запальними захворюваннями статевих органів, клітин, що сформувалися послідовно за всіма стадіями сперматогенного циклу, нараховувалося у середньому 56,4 \%. Підраховувалися також клітини, які мали порушення в процесі розходження хромосомного апарату та атипічне розходження акросом на стадії утворення сперматид II порядку та сперматозоїдів. У результаті несинергічного розходження акросом утворювалися сперматозоїди з роздвоєнною головкою, нетиповою сформованою шийкою та подвійними джгутиками. Статевих клітин із подвоєнною головкою нараховувалося $32,4 \%$, патологією шийки - 7,21 \%, подвійними джгутиками $3,72 \%$ (табл. 2).

Висновки та перспективи подальших досліджень. 1. Електромагнітне поле різного походження негативно впливає на органи та системи, зокрема на статеву систему чоловіків. Наслідком цього є зміни, що визначаються в вигляді зменшення поступальних рухів статевих клітин, а також видозмінення форм сперматозоїдів у процесі сперматогенезу. 2. Вплив електромагнітного поля призвів до змін у структурі життєздатних

Таблиия 1

Відсоткове співвідношення життсздатних сперматозоїдів яєчок чоловіків після вПливу ЕМП

\begin{tabular}{|c|c|c|c|c|c|}
\hline Кількість & Загальна кіль- & \multicolumn{3}{|c|}{ Рухомість сперматозоїдів, \% } & \multirow{2}{*}{ жеживі } \\
\cline { 3 - 6 } сперматозоїдів, & кість спермато- & \multicolumn{3}{|c|}{ живі } \\
\cline { 3 - 6 } млн/мл & зоїдів, млн. & малорухомі & без поступальних рухів & нерухомі & \\
\hline 56,4 & 216,55 & 37,4 & 6,54 & 56,33 & 49,81 \\
\hline
\end{tabular}

Відсоткове співвідношення нормальних і патологічних форм сперматозоїдів яєчок чоловіків після впливу ЕМП

\begin{tabular}{|c|c|c|c|}
\hline \multirow{2}{*}{ Нормальні форми сперматозоїдів, \% } & \multicolumn{3}{|c|}{ Патологія форми сперматозоїдів, \% } \\
\cline { 2 - 4 } & головки & шийки & Хвоста \\
\hline 56,4 & 32,6 & 7,21 & 3,72 \\
\hline
\end{tabular}


клітин в яєчках чоловіків у бік збільшення малорухомих клітин до 37,4 \%. 3. Вплив електромагнітного поля призводив до порушення процесу сперматогенезу на етапах формування сперматид II порядку та сперматозоїдів із утворенням клітин із подвійними головками, деформованими шийками та подвійними джгутиками. Найбільшої деформа- ції піддалися головки сперматозоїдів, які у структурі патологічних клітин досягли рівня 32,6 \%. 4. Наведені відомості засвідчують про те, що електромагнітне поле негативно впливає на процес сперматогенезу, що може призвести до виникнення безпліддя у чоловіків і збільшення ролі чоловічого фактора у структурі подружнього безпліддя.

\section{Список використаної літератури}

1. Брагина ЕЕ, Сорокина ТМ. Генетически обусловленные формы патозооспермии. Обзор литературь и результаты исследований. Андрология и генитальная хирургия. 2015;16(3):29-31.

2. Ткачихин ВС. Вплив виробничих факторів на специфічні функиії чоловічого організму. Медичні перспективи. 2017;3(1):129-34.

3. Евдокимов ВВ, Туровский ВБ, Муренеи ВИ. Подвижность сперматозоидов при воздействии перекиси водорода. Андрология и генитальная хирургия. 2015;1:69-72.

4. Брагина ЕЕ, Арифулин ЕА, Лазарева ЕМ. Нарушение конденсаџии хроматина сперматозоидов и фрагментаџия ДНК сперматозоидов: есть ли корреляциия? Андрология и генитальная хирургия. 2017; 1:48-53.

5. Штаут МИ. Аспекты морфогенетических преобразований хроматина на прелептотенных стадиях сперматогенеза человека. Андрология и генитальная хирургия. 2016;2:104-7.

6. Курило ЛФ, Хаит СШ. Возможности тестирования проиессов митоза и мейоза женских и мужских половых клеток. Андрология и генитальная хирургия. 2016;4:28-31.

\section{References}

1. Bragina EE, Sorokina TM. Genetycheski obuslovlennye formy patozoospermiy. Obzor literatury i rezultaty issledovaniy [Genetically determined forms of pathozoospermia. Literature review and research results]. Andrologiya i genital'naya khirurgiya. 2015;16(3):29-31. (in Russian).

2. Tkachyshyn VS. Vplyv vyrobnychykh faktoriv na spetsyfichni funktsiyi cholovichogo organizmu [Influence of viral factors on the specific functional functions of the organism]. Medychni perspektyvy. 2017;3(1):12934. (in Ukrainian).

3. Evdokimov VV, Turovskij VB, Murenec VI. Podvizhnost spermatozoidov pri vozdejstvii perekisi vodoroda [Sperm motility when exposed to hydrogen peroxide]. Andrologiya i genital'naya khirurgiya. 2015;1:69-72. (in Russian).

4. Bragyna EE, Arifulin EA, Lazareva EM. Narushenie kondensacii hromatina spermatozoidov i fragmentaciya dnk spermatozoidov: est li korrelyatsiya? [Impaired sperm chromatin condensation and sperm DNA fragmentation: is there a correlation?]. Andrologiya i genital'naya khirurgiya. 2017;1:48-53. (in Russian).

5. Shtaut MI. Aspekty morfogeneticheskih preobrazovanij hromatina na preleptotennyh stadiyah spermatogeneza cheloveka. [Aspects of morphogenetic transformations of chromatin at preleptogenic stages of human spermatogenesis]. Andrologiya i genital'naya khirurgiya.2016;2:104-7. (in Russian).

6. Kurilo LF, Khait SSH. Vozmozhnosti testirovaniya protsessov mitoza i meyoza zhenskikh i muzhskikh polovykh kletok [Possibilities for testing the processes of mitosis and meiosis offemale and male germ cells]. Andrologiya i genital'naya khirurgiya. 2016;4:28-31.(in Russian).

\section{ВИДОИЗМЕНЕНИЕ ФОРМ СПЕРМАТОЗОИДОВ В ЯИЧКАХ МУЖЧИН С ВОСПАЛИТЕЛЬ- НЫМИ ЗАБОЛЕВАНИЯМИ МОЧЕПОЛОВОЙ СИСТЕМЫ}

Резюме. В данной работе представлены сведения о процессе формирования половых клеток у мужчин с воспалительными заболеваниями половых органов, которые подверглись действию электромагнитного поля. Наблюдения за сперматозоидами показало, что живых клеток насчитывалось больше, чем неживых (соответственно - 50,19 \% та 49,81 \%). В процессе наблюдения обнаружено нарушение подвижности клеток в сторону увеличения количества неподвижных клеток до 37,4 \% и малоподвижных до 56,33 \%. Влияние электромагнитного поля приводило к нарушению процесса сперматогенеза на этапе формирования поздних сперматид и сперматозоидов. В результате некоригированного расхождения акросом половых клеток формировались клетки с двойными головками, деформированными шейками и раздвоенными жгутиками. Наибольшей деформации подверглись головки сперматозоидов, которых насчитано 32,6 \%, изменений структур шейки - 7,21 \% и изменений структур хвостиков - 3,72 \%. Ключевые слова: электромагнитное поле, сперматозоид, акросома, подвижность. 
MODIFICATION OF FORMS OF SPERM IN THE TESTICLES OF MEN WITH INFLAMMATORY DISEASES OF THE GENITOURINARY SYSTEM

Abstract. This paper presents information on the process of the formation of germ cells in men with inflammatory diseases of the genital organs that have been exposed to electromagnetic fields.Observations of spermatozoa showed that there were more living cells than non-living (respectively, 50.19\% and 48.81\%).During the observation disorder of cell motility was detected in the direction of increasing the number of motionless cells to $37.4 \%$ and sedentary to $56,33 \%$.The influence of the electromagnetic field led to disruption of the spermatogenesis process at the stage of formation of late spermatids and spermatozoa.As a result of the noncoordinated divergence by acrosome of germ cells, cells with double heads, deformed necks and bifurcated flagella were formed.The sperm heads, which accounted for $32.6 \%$, subjected to greatest deformation, changes in the structures of the cervix are defined $7.21 \%$ and changes in the structures of the tails $-3.72 \%$.

Key words: electromagnetic fields, spermatozoa, acrosome, motility.

Відомості про авторів:

Шарапова Олена Миколаївна - кандидат медичних наук, викладач кафедри клінічної анатомії, анатомії і оперативної хірургії ДЗ «Дніпропетровська медична академія MO3 України».

Information about author:

Sharapova Olena M. - Candidate of Medical Sciences, lecturer of the Department of Clinical Anatomy, Anatomy and Operative Surgery, DZ «Dnipropetrovsk Medical Academy of Medical Sciences of Ukraine».

Надійшла 11.06 .2019 p. Рецензент - проф. Хмара Т.В. (Чернівці) 